\title{
Biocompatibility of Polylactic Acid as a Bone Substitute: An In Vitro Study
}

\author{
Meenapriya $\mathrm{M}^{1}$, Ashok V², Kiran Kumar ${ }^{3}$ and Dhanraj Ganapathy ${ }^{4}$ \\ ${ }^{1}$ Saveetha Dental College and Hospitals, Saveetha Institute of Medical and \\ Technical Sciences, Saveetha University, Chennai - 600 077, Tamilnadu, India. \\ ${ }^{2}$ Professor and Head (Admin), Department of Prosthodontics Saveetha Dental College \\ and Hospitals Saveetha Institute of Medical and Technical Sciences, Saveetha University \\ Chennai, India \\ ${ }^{3}$ Senior Lecturer Department of Prosthodontics Saveetha Dental College and Hospitals \\ Saveetha Institute of Medical and Technical Sciences, Saveetha University Chennai, India \\ 4Professor and Head (Academics), Department of Prosthodontics Saveetha Dental College and \\ Hospitals Saveetha Institute of Medical and Technical Sciences, Saveetha University Chennai, India
}

\section{ABSTRACT}

Biocompatibility is defined as the ability of the bone material to perform appropriate host response in specific applications. Different bone substitutes can be used. These bone substitutes are derived from biological products as well as the synthetic products. The biological products are derived from the demineralized bone matrix, hydroxyapatite, growth factors and the synthetic products are derived from tri-calcium phosphate ceramics, or polymer based substitutes. This study aims at the biocompatibility of poly lactic acid which can be used as a bone substitute. The L929 Fibroblast cell lines were used for assessing the biocompatibility. The cell lines are maintained in a humidified atmosphere at 37degree C. Cell viability is assessed using MTT assay and the cell growth is assessed using the $\mathrm{BrDu}$ cell proliferation assay. The readings are done in ELISA readers at 570nm and 450nm respectively. The results are statistically analyzed by ANOVA. Even in the minimum concentration, $89.4 \%$ of the cells are viable and in the maximum concentration $100.7 \%$ of the cells are viable. The cell growth increased as the concentrations of the PLA increased. The in vitro biocompatibility of PLA exhibited satisfying biological security with favorable cell adhesion, spreading and proliferation.

\section{KEY WORDS: PLA, BIOCOMPATIBILITY, ASSAY, L929 FIBROBLAST CELL LINES, CYTOTOXICITY.}

\section{INTRODUCTION}

The applications of poly lactic acid (PLA), poly glycolic acid and their copolymers is used currently in several

\section{ARTICLE INFORMATION}

*Corresponding Author: ashok@saveetha.com

Received 27th July 2020 Accepted after revision 23rd Sep 2020

Print ISSN: 0974-6455 Online ISSN: 2321-4007 CODEN: BBRCBA

Thomson Reuters ISI Web of Science Clarivate Analytics USA and Crossref Indexed Journal

\section{Clarivate Crossef}

NAAS Journal Score 2020 (4.31) SJIF: 2020 (7.728)

A Society of Science and Nature Publication,

Bhopal India 2020. All rights reserved.

Online Contents Available at: http//www.bbrc.in/

Doi: http://dx.doi.org/10.21786/bbrc/13.8/144 practices. The applications of these as bone replacement devices which are the bone plates, bone screws, pins and nails and also as scaffolds for soft and hard tissue replacement is carried out widely. Poly lactic acid degrades into lactic acid and glycolic acid. (Athanasiou, Niederauer and Agrawal, 1996) When these biomaterials degrade, they result in mass loss and eventually lead to loss of strength and its stiffness. Biomaterials or the bone substitutes have features such as physico-chemical and biological properties and they are suitable to fabricate scaffolds for tissue engineering. These biomaterials or bone substitutes are classified as natural and synthetic polymers. The most commonly used biomaterials for fabricating three-dimensional scaffolds in applications

$$
239
$$


such as orthopaedic practices and tissue engineering are the PLA and PGA as well as PLGA copolymers. (Gentile et al., 2014).

Bone defect-related infections are quite common in clinics, especially in open bone fracture and trauma, which affects the bone union and are normally regarded as contraindications for bone substitutes. Repairing these bone related infections and deficiencies of bone are necessary and important in clinical treatment. It is difficult to select an appropriate bone substitute to serve as the bone regeneration material, which should be drug-loaded and sustained ability and high ossification bioactivity. (Lian et al., 2013) For clinical bone transplantations, tissue -engineering techniques based on the delivery of the cells to the defect through the use of three dimensional scaffold and biomaterials are to be studied. Three-dimensional scaffolds used are made of polymers and in the earlier study it is shown that the superficial gas foaming of PLA polymers can be used to obtain the porous structures with controlled parameters particularly important for bone tissue engineering. (Montjovent et al., 2005) The polymers used in these bone engineering have thermoset elastomeric properties. According to previous studies, the polymers used exhibit low elasticity and bone resorption.(Wang et al., 2019).

Previously our department has published extensive research on various aspects of prosthetic dentistry ('Evaluation of Corrosive Behavior of Four Nickelchromium Alloys in Artificial Saliva by Cyclic Polarization Test:An in vitro Study', 2017; Ganapathy, Kannan and Venugopalan, 2017; Jain, 2017a, 2017b; Ranganathan, Ganapathy and Jain, 2017; Ariga et al., 2018; Gupta, Ariga and Deogade, 2018; Anbu et al., 2019; Ashok and Ganapathy, 2019; Duraisamy et al., 2019; Varghese, Ramesh and Veeraiyan, 2019), this vast research experience has inspired us to research about.

Therefore, this study aims at evaluating the biocompatibility of polylactic acid which can be used as a bone substitute.

\section{MATERIAL AND METHODS}

Chemicals: The chemicals used for testing the biocompatibility of polylactic acid are 3-(4,5dimethylthiazol-2-yl)-2,5-diphenyltetrazolium bromide), 10\% fetal bovine serum (FBS), 100 units/ml of penicillin, dimethyl sulfoxide (DMSO), human fibroblast cell lines (primary culture), Eagle's minimum essential medium (EMEM), kanamycin, chondroitin sulphate and phosphate-buffered saline.

Polylactic acid (PLA) Preparation: The PLA (50 g) is then melt-blended at $190{ }^{\circ} \mathrm{C}$ with a screw speed of $120 \mathrm{rpm}$ for $4 \mathrm{~min}$ and then cut into samples of $25 \times 25 \mathrm{~mm}$ for further introduction into the cell lines. The sterilization process is carried out before and after the PLA preparation. (Marcos et al., 2019)
Maintenance of cell lines: L929 fibroblast cell lines are used for this study and it is obtained from NCCS Pune. The L929 Cells are allowed to culture in a atmosphere that is humidified at $37{ }^{\circ} \mathrm{C}$ in the DMEM medium along with 10\% fetal bovine serum, L-glutamine ,1\% penicillin $(100 \mathrm{U} / \mathrm{ml})$, and streptomycin $(100 \mu \mathrm{g} /$ $\mathrm{ml}$ ) in a chamber with 95\% air. Followed by this, the cells are detached from one another with 0.25\% EDTA Trypsin. This process of neutralization of the Trypsin is achieved by DMEM containing 10\% FBS and PSGF. The cell lines are mechanically separated using a pipette. There are 96-well plastic culture plates filled with $200 \mu \mathrm{l}$ of medium containing in each well. The culture plates are incubated at $37^{\circ} \mathrm{C}$ in a humidified atmosphere. The incubation chamber had 5\% CO2 and 95\% air and it continued for $24 \mathrm{~h}$ to allow attachment of the cells to the culture plates.

Cell viability by MTT assay: For cell viability test, L929 fibroblast cell lines are cultured in 96-well tissue culture plates. The microplates filled with $100 \mu$ l of cells with a density of $1 \times 105$ as negative control. The cell lines are allowed to adhere for 24 hours, and the DMEM growth medium of $800 \mu \mathrm{l}$ is withdrawn using micropipette. This single layer of cells are washed twice with MEM without FBS for removing the dead cells and excess FBS. $1 \mathrm{ml}$ of MEM medium (without FBS) containing different dilutions of polylactic acid (1.0,2.5, 5.0 and $7.5 \mathrm{mg} / \mathrm{ml})$ are added in respective culture wells; the incubation is carried out for $72 \mathrm{hrs}$. Then $100 \mu \mathrm{l}$ of MTT $(5 \mathrm{mg} / \mathrm{ml}$ in PBS) are added to each well, and the cell lines are incubated for a further $67 \mathrm{hrs}$ in 5\% CO2 incubator. After removal of the medium, $1 \mathrm{ml}$ of DMSO medium is added to each well and tested.

The supernatant is removed and $50 \mu$ l of propanol is added and the plates are gently shaken to solubilize the formed formazan. The MTT media enters the cells and passes into the mitochondria of the cell where it is reduced to an insoluble, coloured (dark purple) formazan product. The plates are placed on an orbital shaker for 15 min and the absorbance is read on an enzyme-linked immunosorbent assay (ELISA) (MINDRAY90) reader at $570 \mathrm{~nm}$. Each test is carried out thrice and the IC50 of the test samples as the percentage survival of the cells are calculated. (Gutiérrez-Prieto et al., 2019)

Invitro Bromodeoxyuridine (BrDu) cell proliferation assay: The $10 \mathrm{mM}$ stock solution of BrdU assay is prepared by dissolving $3 \mathrm{mg}$ of BrdU in $1 \mathrm{~mL}$ of water. Then, the $10 \mathrm{mM}$ BrdU stock solution is diluted into a cell culture medium which forms a $10 \mu \mathrm{M}$ BrdU of labeling solution. About L929 cell density (2x105cells/ well) in $100 \mu \mathrm{l}$ medium is plated in 96-well plate and incubated with respective test substance Polylactic acid $(1.0-7.5 \mathrm{mg} / \mathrm{ml})$. This is followed by incubation for 72 hrs. Add prepared $10 \mu \mathrm{l}$ of $10 \mathrm{mM}$ BrdU solution into each well. Place the cells inside the incubator for $24 \mathrm{hrs}$. Centrifuge the culture plate at $300 \mathrm{xg}$ for $10 \mathrm{~min}$, and then remove the media. 
Add $100 \mu \mathrm{l}$ of the fixing solution, to each well. This is carried out at room temperature for $30 \mathrm{~min}$. After the solution is removed, add $100 \mu \mathrm{l} /$ well of prepared $1 \mathrm{X}$ detection antibody solution, which is placed at room temperature for 1 hour. The solution is discarded and the culture plates are washed 3 times with $1 \mathrm{X}$ Wash Buffer. The $100 \mu \mathrm{l} /$ well of prepared $1 \mathrm{X}$ HRP-conjugated secondary antibody solution is added and incubated at room temperature for $30 \mathrm{~min}$. Then $100 \mu \mathrm{l}$ TMB substrate is added and then incubated for $30 \mathrm{~min}$ at room temperature. Then $100 \mu \mathrm{l}$ stop solution is added and absorbance read at $450 \mathrm{~nm}$. (Simon et al., 2002)

Statistical analysis: Statistical analysis done by SPSS and significance are determined by one-way analysis of variance (ANOVA) and post hoc least-significant difference test. The $p$ values less than 0.05 are considered significant.

\section{RESULTS AND DISCUSSION}

Table 1. This table represents the cytotoxicity testing conducted by MTT assay. Values are expressed as Mean \pm SEM $(n=3) ;{ }^{*} P<0.05$, statistically significant as compared with Negative control. aP<0.05, statistically significant as compared with positive control. Other groups are showing no cytotoxicity as compared with standards.

\begin{tabular}{|l|c|c|c|}
\hline S.No & Treatment & $\begin{array}{c}\text { Conc } \\
(\mathrm{mg} / \mathrm{ml})\end{array}$ & Mean \pm SEM \\
\hline 1 & L929 untreated cells & - & $0.519 \pm 0.05$ \\
\hline 2 & Polylactic acid & 1.0 & $0.464 \pm 0.0^{*}$ \\
\hline 3 & PA & 2.5 & $0.470 \pm 0.02$ \\
\hline 4 & PA & 5.0 & $0.501 \pm 0.04$ \\
\hline 5 & PA & 7.5 & $0.523 \pm 0.05$ \\
\hline 6 & Chondroitin sulphate & 5.0 & $0.533 \pm 0.05$ \\
\hline
\end{tabular}

Biomaterials or bone substitutes are the materials used for medical purposes, and these materials interact with the complex biological living systems. Bone substitutes can take any form and result in complex system interactions. It can be used in the course of any therapeutic procedures or diagnostic procedures, in human or veterinary medicine. As reported previously, the need for appropriate materials as bone substitute to repair and reconstruct bone defects due to trauma or any disease began in the early 20th century. Different materials are available as bone substitutes at present. In a study conducted previously for the use of ceramics as implant materials, it has stated that the biocompatibility and osteoconductive properties provide ceramics with sufficient qualities and it can be used as implant materials for different applications throughout the body. (Bongio et al., 2010)

According to previous studies, polylactic acid (PLA) or polylactide is a thermoplastic material and biodegradable aliphatic polyester which is derived from naturally occurring organic acid(lactic acid) as well as other synthetic substances. Due to its biocompatibility and complete biodegradability, PLA based polymeric materials are ideal for the preparation of various polymeric devices used for different applications. PLA constitutes three dimensional scaffolds that stimulate the cells and tissues for its proliferation and osteogenic differentiation in bone tissue engineering.

Figure 1: The graph represents the percentage of cell viability after $72 \mathrm{hrs}$. Values are expressed as Mean \pm SEM ( $\mathrm{n}=3)$; ${ }^{*} \mathrm{P}<0.05$, statistically significant as compared with Negative control. aP<0.05, statistically significant as compared with positive control. Other groups are showing no cytotoxicity as compared with standards.

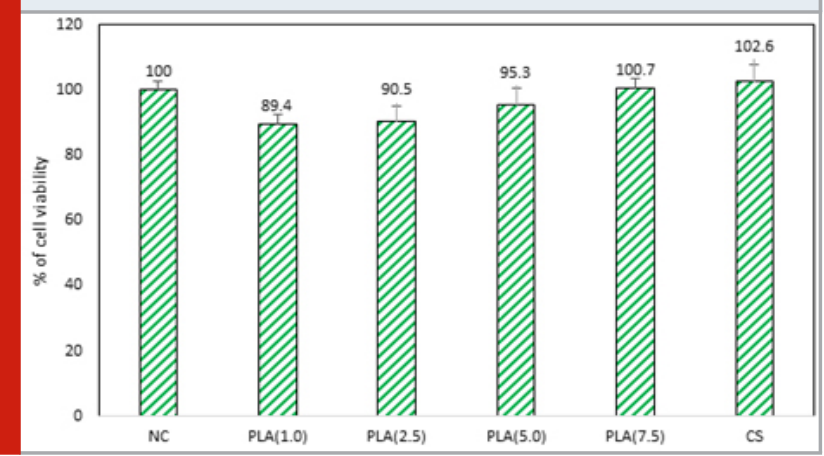

Figure 2: The graph represents the percentage of cell proliferation (BrDu assay) after 72hrs. Values are expressed as Mean \pm SEM $(n=3) ;{ }^{* * *} p<0.001$, statistically significant as compared with Negative control. ap $<0.05$, statistically significant as compared with positive control.

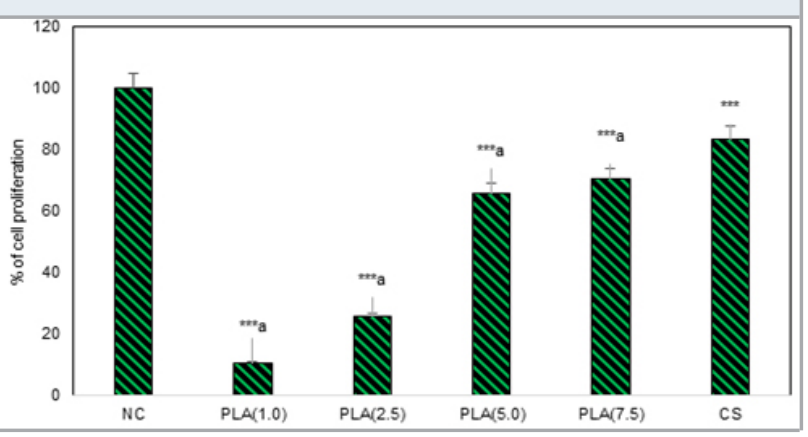

Study conducted on the biocompatibility and osteogenesis of poly (ortho ester) compared with polylactic acid revealed that osteogenic and osteo quantum indices were lower in composites of PLA. The lower osteogenic index is explained by unabsorbed carriers, which results in higher wet weight of the recovered implants. (Solheim et al., 2000) A study focused on investigating the effects of different percentage inclusions of the same PG composition on the properties of the composite foams. Addition of ceramics or glass particles to polymer matrices should improve its mechanical properties, provided that there is good adhesion between the two phases. (Georgiou et al., 2007) In a study conducted for the biological activity of PLA, the cell proliferation of hMSCs cells was significantly comparable between the composite and the polymer control which does not 
contain ceramic. The expression of ALP was higher on the composite materials. (Danoux et al., 2014) When tissue implantation is done, the PLA polymer is coated by phagocytic cells and a fibrous capsule, which denotes a foreign body reaction. (Silva et al., 2018).

Scaffolds containing higher PLA or PLGA can be used as bone substitute materials, and those with lower PLA or PLGA contents can be used for cell culture. (Cui et al., 2005) Earlier studies were also based on the FDM technique. They reported successfully that the PLA discs can be manufactured from these biomaterial poly lactic acids based on this FDM technique. But these techniques did not alter the biocompatibility of PLA and it remained as the safest material. The studies conducted with the human fetal osteoblasts showed no cell inhibiting effects and toxicity. These osteoblasts when allowed for growth on PLA showed reduced growth than the polystyrene. (Wurm et al., 2017) (Lanao et al., 2013) Studies conducted based on 3D printed PLA scaffolds had excellent osteogenic potentials and biodegradation. They showed no inflammatory reactions. Therefore, it was reported that these 3D PLA have very important applications in bone tissue engineering. It can be used as grafts in reconstructive surgery. (Zhang et al., 2016)

\section{CONCLUSION}

Since polylactic acid [PLA] has shown good cell viability and cell proliferation, it can be considered as the safest and biocompatible material which can be used as a bone substitute. Hence, bone defects continue as a critical problem in surgery and many studies are being conducted to find the alternative techniques for bone substitutes. In accordance with the earlier studies conducted, it is concluded that though the improvement on these bone substitutes is conducted through research, human bone grafts persist to be the most effective bone substitutes to replace bone loss. (Ruhé et al., 2005) (Campana et al., 2014) 3D printed bone scaffold using the PLA material can replace the other types of bone grafts since the form and shape can be predetermined before the surgery.

\section{ACKNOWLEDGEMENTS}

This study was supported by Bright Care Research Centre Pvt Ltd, Chennai-600 014, TamilNadu, India. This study was supported by Saveetha Dental College and Hospitals, Saveetha Institute of Medical and Technical Sciences, Saveetha University, Chennai.

Conflict of Interest: There were no conflicts of interest as declared by the authors.

\section{REFERENCES}

Anbu, R. T. et al. (2019) 'Comparison of the Efficacy of Three Different Bone Regeneration Materials: An Animal Study', European journal of dentistry, 13(1), pp. 22-28.

Ariga, P. et al. (2018) 'Determination of Correlation of Width of Maxillary Anterior Teeth using Extraoral and
Intraoral Factors in Indian Population: A Systematic Review', World Journal of Dentistry, 9(1), pp. 68-75. Ashok, V. and Ganapathy, D. (2019) 'A geometrical method to classify face forms', Journal of oral biology and craniofacial research, 9(3), pp. 232-235.

Athanasiou, K. A., Niederauer, G. G. and Agrawal, C. M. (1996) 'Sterilization, toxicity, biocompatibility and clinical applications of polylactic acid/polyglycolic acid copolymers', Biomaterials, 17(2), pp. 93-102.

Bongio, M. et al. (2010) 'Development of bone substitute materials: from "biocompatible" to "instructive", Journal of Materials Chemistry, p. 8747. doi: 10.1039/ c0jm00795a.

Campana, V. et al. (2014) 'Bone substitutes in orthopaedic surgery: from basic science to clinical practice', Journal of materials science. Materials in medicine, 25(10), pp. 2445-2461.

Cui, F. et al. (2005) 'Nano-calcium phosphates/collagen based bone substitute materials', US Patent.

Duraisamy, R. et al. (2019) 'Compatibility of Non Original Abutments With Implants: Evaluation of Microgap at the Implant-Abutment Interface, With Original and Non original Abutments', Implant dentistry, 28(3), pp. 289-295.

Evaluation of Corrosive Behavior of Four Nickelchromium Alloys in Artificial Saliva by Cyclic Polarization Test:An in vitro Study' (2017) World Journal of Dentistry, 8(6), pp. 477-482.

Ganapathy, D. M., Kannan, A. and Venugopalan, S. (2017) 'Effect of Coated Surfaces influencing Screw Loosening in Implants: A Systematic Review and Meta-analysis', World Journal of Dentistry, 8(6), pp. 496-502.

Gentile, P. et al. (2014) 'An overview of poly (lacticco-glycolic) acid (PLGA)-based biomaterials for bone tissue engineering', International journal of molecular sciences. Multidisciplinary Digital Publishing Institute, 15(3), pp. 3640-3659.

Georgiou, G. et al. (2007) 'Polylactic acid-phosphate glass composite foams as scaffolds for bone tissue engineering', Journal of biomedical materials research, 80B(2), pp. 322-331.

Gupta, P., Ariga, P. and Deogade, S. C. (2018) 'Effect of Monopoly-coating Agent on the Surface Roughness of a Tissue Conditioner Subjected to Cleansing and Disinfection: A Contact Profilometric Study', Contemporary clinical dentistry, 9(Suppl 1), pp. S122S126.

Gutiérrez-Prieto, S. J. et al. (2019) 'Elaboration and Biocompatibility of an Eggshell-Derived Hydroxyapatite Material Modified with Si/PLGA for Bone Regeneration in Dentistry', International journal of dentistry, 2019, p. 5949232. 
Jain, A. R. (2017a) 'Clinical and Functional Outcomes of Implant Prostheses in Fibula Free Flaps', World Journal of Dentistry, 8(3), pp. 171-176.

Jain, A. R. (2017b) 'Prevalence of Partial Edentulousness and Treatment needs in Rural Population of South India', World Journal of Dentistry, 8(3), pp. 213-217.

Lanao, R. P. F. et al. (2013) 'Physicochemical properties and applications of poly (lactic-co-glycolic acid) for use in bone regeneration', Tissue engineering. Part B, Reviews. Mary Ann Liebert, Inc. 140 Huguenot Street, 3rd Floor New Rochelle, NY 10801 USA, 19(4), pp. 380-390.

Lian, X. et al. (2013) 'Antibacterial and biocompatible properties of vancomycin-loaded nano-hydroxyapatite/ collagen/poly (lactic acid) bone substitute', Progress in Natural Science: Materials International, 23(6), pp. 549-556.

Marcos, J. J. L. et al. (2019) 'Physical and Mechanical Properties of Composite Scaffolds with or without Collagen Impregnation', NATO Advanced Science Institutes series E: Applied sciences. Multidisciplinary Digital Publishing Institute, 9(20), p. 4296.

Montjovent, M.-0. et al. (2005) 'Biocompatibility of Bioresorbable Poly(L-lactic acid) Composite Scaffolds Obtained by Supercritical Gas Foaming with Human Fetal Bone Cells', Tissue Engineering, pp. 1640-1649. doi: 10.1089/ten.2005.11.1640.

Pawar, R. P. et al. (2014) 'Biomedical Applications of Poly(Lactic Acid)', Recent Patents on Regenerative Medicine, pp. 40-51. doi: 10.2174/2210296504666140 402235024.

Ranganathan, H., Ganapathy, D. M. and Jain, A. R. (2017) 'Cervical and Incisal Marginal Discrepancy in Ceramic Laminate Veneering Materials: A SEM Analysis', Contemporary clinical dentistry, 8(2), pp. 272-278.

Ruhé, P. et al. (2005) 'Calcium phosphate ceramics for bone tissue engineering', BocaRaton, FL: CRC..

Silva, D. da et al. (2018) 'Biocompatibility, biodegradation and excretion of polylactic acid (PLA) in medical implants and theranostic systems', Chemical Engineering Journal, pp. 9-14. doi: 10.1016/j.cej.2018.01.010.

Simon, C. G., Jr et al. (2002) 'Preliminary report on the biocompatibility of a moldable, resorbable, composite bone graft consisting of calcium phosphate cement and poly (lactide-co-glycolide) microspheres', Journal of orthopaedic research: official publication of the Orthopaedic Research Society. Wiley Online Library, 20(3), pp. 473-482.

Solheim, E. et al. (2000) 'Biocompatibility and effect on osteogenesis of poly (ortho ester) compared to poly (DLlactic acid)', Journal of Biomedical Materials Research: An Official Journal of The Society for Biomaterials and The Japanese Society for Biomaterials. Wiley Online Library, 49(2), pp. 257-263.

Varghese, S. S., Ramesh, A. and Veeraiyan, D. N. (2019) 'Blended Module-Based Teaching in Biostatistics and Research Methodology: A Retrospective Study with Postgraduate Dental Students', Journal of dental education, 83(4), pp. 445-450.

Wang, Y. et al. (2019) 'Enhanced osteogenic proliferation and differentiation of human adipose-derived stem cells on a porous n-HA/PGS-M composite scaffold', Scientific reports, 9(1), p. 7960.

Wurm, M. C. et al. (2017) 'In-vitro evaluation of Polylactic acid (PLA) manufactured by fused deposition modeling, Journal of biological engineering, 11, p. 29.

Zhang, H. et al. (2016) 'Three dimensional printed macroporous polylactic acid/hydroxyapatite composite scaffolds for promoting bone formation in a critical-size rat calvarial defect model', Science and Technology of Advanced Materials, 17(1), pp. 136-148. 